\author{
A. Irekti ${ }^{*}$, M. Oualit ${ }^{1}$, H. Siahmed ${ }^{2}$, D. Buncianu ${ }^{3}$, F. Zibouche ${ }^{1}$ \\ ${ }^{1}$ Department of Chemistry, Faculty of Sciences, University M'Hamed Bougara de \\ Boumerdes, Avenue de l'indépendance, 35000 Boumerdes, Algeria \\ ${ }^{2}$ Laboratory of Fibrous Polymers Treatment and Forming (L.T.M.F.P), University M'Hamed \\ Bougara Boumerdes, Avenue de l'independance, Boumerdes 35000, Algeria \\ ${ }^{3}$ University Politehnica Timisoara, Bdul. Mihai Viteazu No.1, Romania \\ *a.irekti@univ-boumerdes.dz
}

\title{
EFFECT OF BLACK LIQUOR FROM DATE PALM ON THE WORKABILITY AND COMPRESSIVE STRENGTH OF PORTLAND CEMENT AND CONCRETE
}

\begin{abstract}
Abstract - Lignin is the second most abundant natural polymer. Due to the high content of carbon and hydrogen $(\mathrm{C}-\mathrm{H}, \mathrm{C}-\mathrm{C}, \mathrm{C}=\mathrm{O})$, it can be used as a potential dispersant for cement matrix. The objective of this study is to extract lignin from date palm and study its effect in the form of black liquor (BL) on the rheological and physicmechanical properties of the cements and concrete. The lignin in black liquor form represents approximately 30 $\mathrm{wt} \%$ dry weight of date palm. It is a heteropolymer composed primarily of methoxylated phenylpropylene alcohol monomeric units interconnected by a variety of stable carbon-carbon and carbon-oxygen-carbon (ether and esters) linkages. The results found show the positive effect on the workability of cement and concrete and confirms its dispersion effect by improving compressive strength of concrete during the early and the later ages of hydration.
\end{abstract}

Keywords: black liquor (BL), date palm, cement, rheological properties, compressive strength

\section{INTRODUCTION}

Interest in renewable feedstock for the chemical industry has increased considerably over the last decades, mainly due to environmental concerns and foreseeable shortage of fossil raw materials. Lignocellulosic biomass is an abundant source of bio-based raw material that is readily available and can be utilized as an alternative source for chemical production [1-4].

Lignin is one of the important chemical constituents of lignocellulosic materials in wood and it is one of the most abundant biopolymers in nature. Despite extensive investigation, the complex and irregular structure of lignin is not fully understood. The physical property and the chemical characteristics of lignin vary not only between different wood species, but also according to the method of isolation. Moreover, the molecular structure and function groups differ for the various type of lignin [4-9]. 
Lignin, a heterogeneous three-dimensional biopolymer, is one of the building blocks of lignocellulosic biomass. It is a complex biopolymer, which contains a large number of functional groups, including aliphatic and aromatic hydroxyl groups, carbohylic groups and methoxy groups in its structure that is why it shows potential capacities for process of sorption [10-11]. Lignin is a highly cross-linked polymer with a three-dimentional structure which can provide large surface area and pores volumes $[8,12,13]$.

Based on the source (softwood, hardwood or annual crop) and isolation method (Kraft, organosolv, sulfite or preenzymatic treatment), there are significant variations in lignin structure and properties. The first step in using lignin as biobased feedstock is to make sure that specific lignin is suitable for intended application. Complete characterization of lignin and measuring its chemical, physical and thermal properties can help to predict its suitability $[14,15]$.

In this study, we extracted the lignin by the Kraft process from the date-palm wood of the TOLGA-Algeria region. After extraction and sulfonation the Kraft lignin has been valued as superplasticizer in concrete. Its physical characteristics and its rheological effect to the cement matrix have been studied.

\section{MATERIALS AND METHODS}

\section{$\underline{\text { Kraft Lignin }}$}

Lignin is a complex chemical compound and the only aromatic polymer present in wood; it is concentrated mainly in the region of the middle lamella. The amount of lignin in normal wood is $20 \%-35 \%$ depending on the different wood species [16].

Lignin is an aromatic heteropolymer composed of three main monomers: phydroxyphenol $(\mathrm{H})$, guaiacyl $(\mathrm{G})$, and syringyl (S)-with varying degrees of methylation (Fig. 1). It is the nature of lignin and its bonds to hemicellulose and cellulose that determine how difficult it will be to breakdown lignocelluloses $[17,18]$.
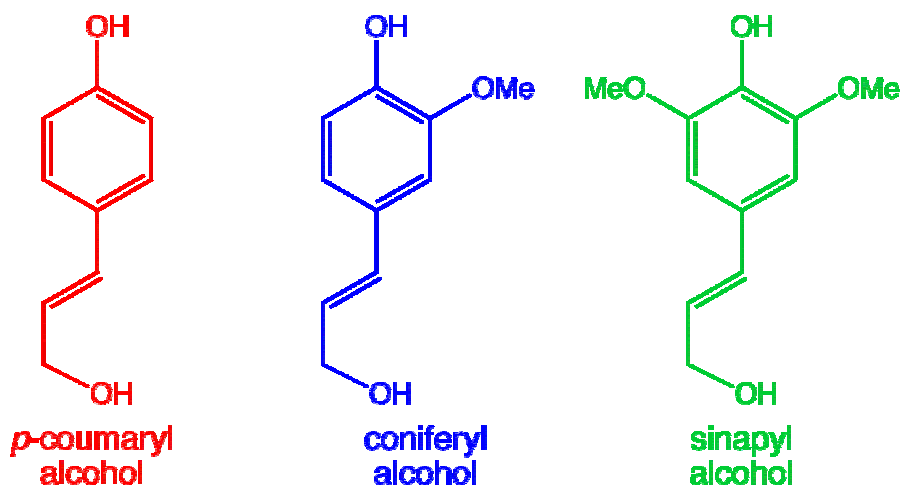

Fig. 1. Lignol Structures. Chemical structure of lignin alcohol precursors, the lignols, that incorporate into lignin as phenylpropanoids. The three main lignin phenylpropanoids are: p-hydroxypheyl $(H)$, guaiacyl $(G)$, and syringyl (S) $[17,18]$

\section{Isolation of lignin}

The wood species sampled is the date palm. This species was chosen because of its great abundance in our country. Harvesting of this "date palm trunk" sampling was carried out in the Dkhila Tolga area of Biskra, Algeria. 


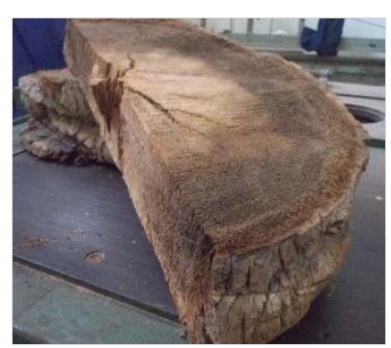

(a)

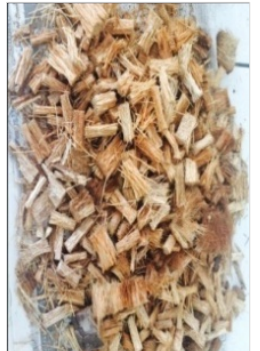

(b)

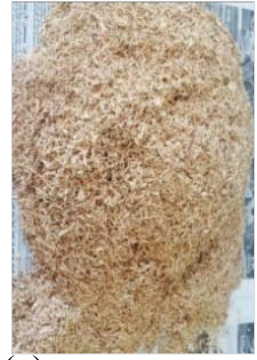

(c)

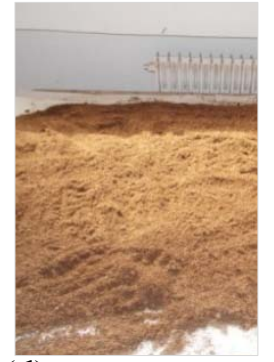

(d)

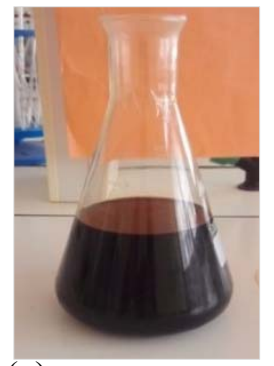

(e)

Fig. 2. Steps of processing of date palm wood: (a) Date palm trunk, (b), (c) The date-palm wood chips, (d) The milled wood, (e) The Black Liquor

Accordingly, the so-called dissolved wood lignin (DWL) method was developed by total dissolution of ball-milled wood. The date-palm wood chips, collected after shredding the tree trunk were dried (vacuum, $120^{\circ} \mathrm{C}, 48 \mathrm{~h}$ ) and milled with a cutting mill to pass a $0.8 \mathrm{~mm}$. The milled wood was extracted with toluene-ethanol/water (9:1) in a Soxhlet apparatus for 24h. The extractive free wood was dried $\left(105^{\circ} \mathrm{C}\right)$ for several days [19]. The dry wood was milled with a planetary ball mill (Retsch PM2) with steel jars and steel balls under conditions specified below (Fig. 2).

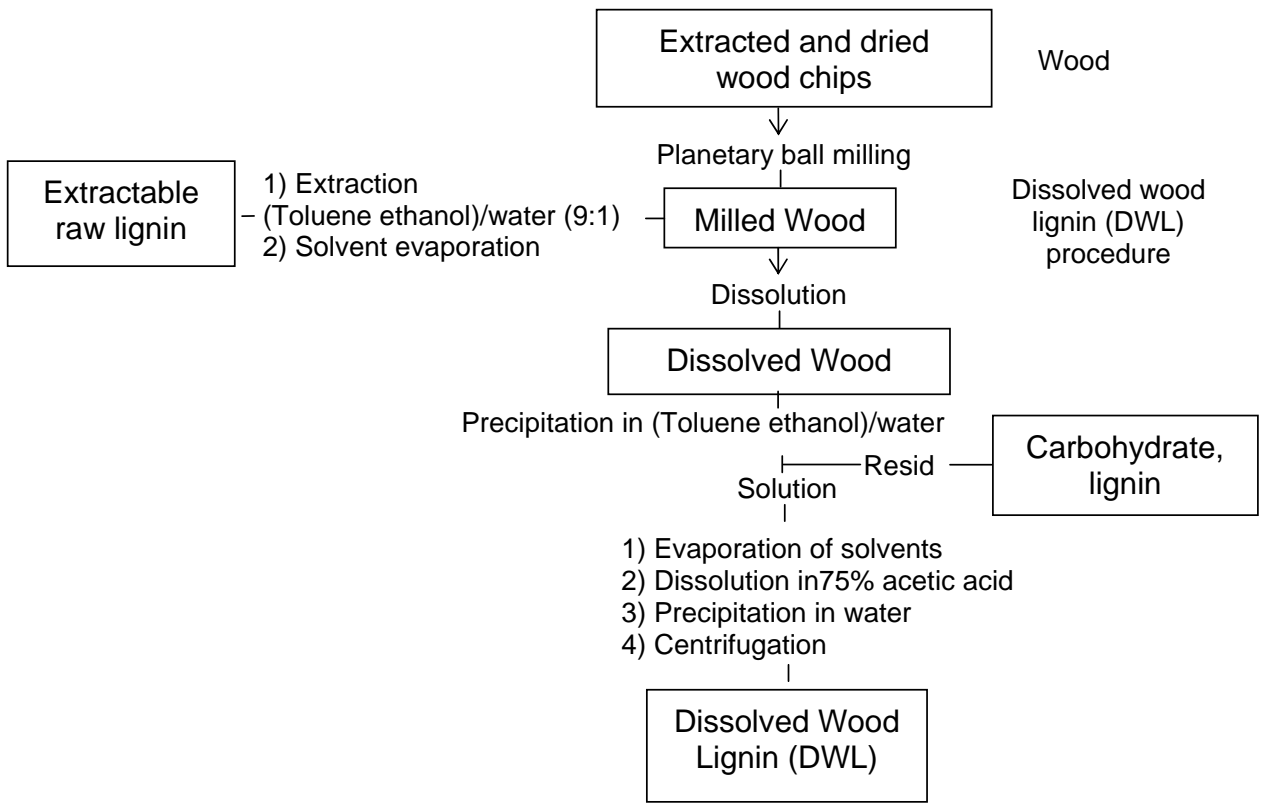

Fig. 3. Lignin isolation procedure (DWL) [19]

The solution collected was acidified to ( $\mathrm{pH}$ 1.7), by using a dilute $\mathrm{H}_{2} \mathrm{SO}_{4}$ solution, and lignin was precipitated and separated by centrifugation. Upon completion, the wood meal dioxane mixture was filtered on a Buchner funnel and the residue was washed with a dioxane solution (9:1), after which it was neutralized by adding solid $\mathrm{Na}_{2} \mathrm{CO}_{3}$ and filtered. The filtrate was concentrated in a vacuum evaporator at $50{ }^{\circ} \mathrm{C}$, and a concentrated dioxane solution was added dropwise, to precipitate the lignin. Finally, the precipitated lignin was washed with distilled water and dried (Fig.3).

Typical yields of lignin after a final extraction step were $31 \%$ on dry wood. Table 1 gives Properties of lignin in the form of Black Liquor. 
Table 1. Properties of lignin (Black Liquor)

\begin{tabular}{cccc}
\hline Density & $\mathrm{pH}$ & Water solubility, $(\mathrm{g} / \mathrm{L})$ & Dry extract $(\%)$ \\
\hline 1.12 & 12.16 & 1,9 & 7,9 \\
\hline
\end{tabular}

\section{Black Liquor FT-IR Analyses}

FT-IR analysis was used to characterize the absorption bands for representative functional groups in the lignin extracts. Table 2 lists the peaks observed, as well as their assignments using previously described biomass samples in the literature [20-25].

The FTIR spectrum of lignin is shown in Fig. 4. Bands were assigned according to Shen et al. (2010) [26], and Yuan et al. (2011) [27]. The bands around 3350-3400 $\mathrm{cm}^{-1}$ is due to strong $\mathrm{O}-\mathrm{H}$ stretching. Peaks at $2953-3080 \mathrm{~cm}^{-1}$ indicate apparent $\mathrm{C}-\mathrm{H}$ stretching in methyl and methylene groups.

Table 2. Absorption peak assignment in FT-IR spectra of Black Liquor

\begin{tabular}{|c|c|}
\hline Approximate Band $\left(\mathrm{cm}^{-1}\right)$ & Assignment \\
\hline $3350-3400$ & O-H stretching in hydroxyl groups \\
\hline $2953-3080$ & $\begin{array}{l}\mathrm{C}-\mathrm{H} \text { stretching in methyl and methylene groups, } \mathrm{C}-\mathrm{H} \text { stretching aromatic } \\
\text { methoxyl groups }\end{array}$ \\
\hline 1633 & Aromatic skeleton vibrations plus $\mathrm{C}=\mathrm{O}$ stretching \\
\hline 1375 & Aliphatic $\mathrm{C}-\mathrm{H}$ stretching in methyl and phenol $\mathrm{OH}$ \\
\hline 1225 & secondary alcohol and $\mathrm{C}=\mathrm{O}$ stretch \\
\hline 875 & $\mathrm{C}-\mathrm{H}$ vibrations \\
\hline
\end{tabular}

Stretch at $1633 \mathrm{~cm}^{-1}$ corresponds to the existence of $\mathrm{C}=\mathrm{O}$ in unconjugated carbonyls. $\mathrm{C}-\mathrm{H}$ deformations can be found at $1375 \mathrm{~cm}^{-1}$. The $\mathrm{C}=\mathrm{O}$ stretch assigned to syringyl rings is presented at $1225 \mathrm{~cm}^{-1}$ as well as the $\mathrm{C}-\mathrm{H}$ vibrations found at $875 \mathrm{~cm}^{-1}$.

The Black Liquor peaks are typically easier to characterize, and have significant absorbance peaks that enable the clear conclusions derived from the FT-IR spectra and confirms the obtaining of lignin by the method Dissolved Wood Lignin (DWL).

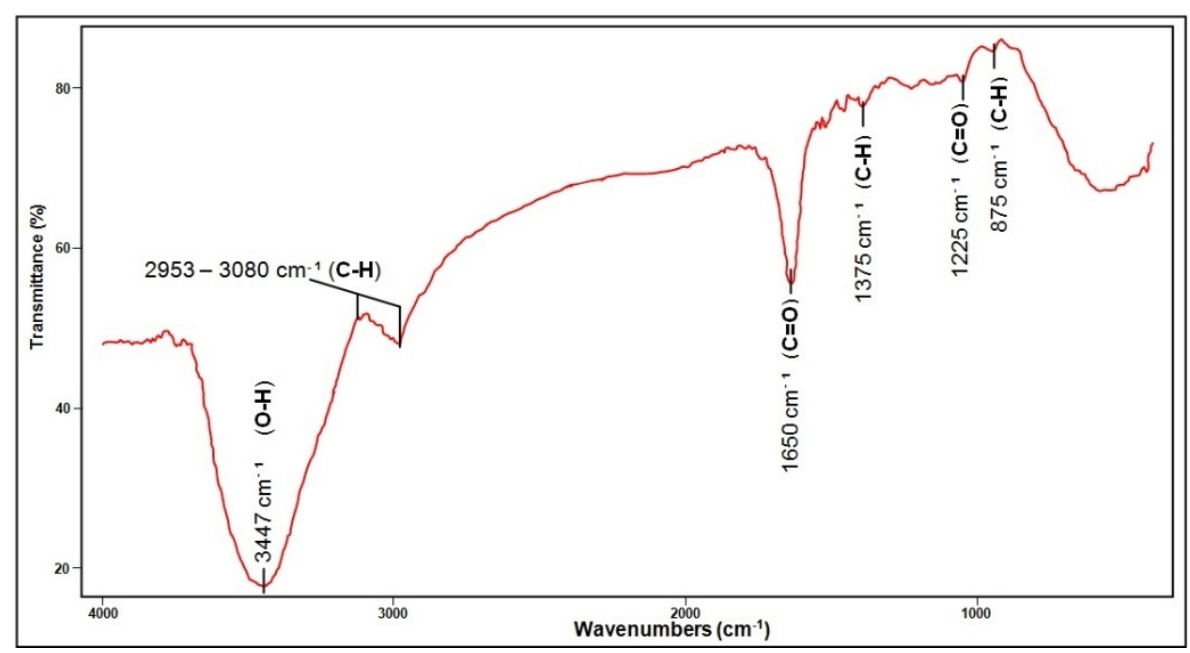

Fig. 4. Fourier transform infrared spectroscopy spectra of black liquor 


\section{Cement}

The cement used in this study is a CPJ-CEM II/A 42.5 type, supplied by GICA Company, Algeria. It is characterized by a Normal consistency of $26.7 \%$ and a finesse following Blaine's method (NA 231) [28] of $5820 \mathrm{~cm}^{2} / \mathrm{g}$. The mineral and chemical compositions of cement are given in the Table 3 and 4, respectively.

Table 3. The cement (CPJ-CEM II/A 42) mineral composition

\begin{tabular}{lccccc}
\hline Mineral composition (\%) & C3S & C2S & C3A & C4AF & Free CaO \\
\hline CPJ-CEM II/A 42.5 & 53.90 & 21 & 7.11 & 11 & $\leq 1$ \\
\hline
\end{tabular}

Table 4. The cement (CPJ-CEM II/A 42.5) chemical composition

\begin{tabular}{|c|c|c|c|}
\hline & \multicolumn{2}{|r|}{ Constituents } & Per cent by Weight (\%). \\
\hline 1. & \multicolumn{2}{|c|}{ Silica $\left(\mathrm{SiO}_{2}\right)$} & 22.88 \\
\hline 2. & \multicolumn{2}{|c|}{ Iron Oxide $\left(\mathrm{Fe}_{2} \mathrm{O}_{3}\right)$} & 5.42 \\
\hline 3. & \multicolumn{2}{|c|}{ Alumina $\left(\mathrm{Al}_{2} \mathrm{O}_{3}\right)$} & 4.24 \\
\hline 4. & \multicolumn{2}{|c|}{ Calcium Oxide $(\mathrm{CaO})$} & 62.93 \\
\hline 5. & \multicolumn{2}{|c|}{ Magnesium Oxide $(\mathrm{MgO})$} & 1.03 \\
\hline 6. & \multicolumn{2}{|c|}{ Total Sulphur $\left(\mathrm{SO}_{3}\right)$} & 1.22 \\
\hline \multirow{2}{*}{$\begin{array}{l}7 . \\
8 .\end{array}$} & \multirow{2}{*}{ Alkalies } & a) Sodium Oxide $\left(\mathrm{Na}_{2} \mathrm{O}\right)$ & 0.24 \\
\hline & & b) Potassium Oxide $\left(\mathrm{K}_{2} \mathrm{O}\right)$ & 0.37 \\
\hline 9. & \multicolumn{2}{|c|}{ Insoluble residue } & 0.78 \\
\hline 10. & \multicolumn{2}{|c|}{ Loss on ignition } & 0.89 \\
\hline
\end{tabular}

\section{$\underline{\text { Admixtures }}$}

A polycarboxylic ether based superplasticizer complying with NA 774 [29] type SIKAFLUID ${ }^{\circledR}-300$, was used. Their properties are presented in Table 5.

Table 5. Properties of superplasticizers SIKAFLUID®-300

\begin{tabular}{ll}
\hline \multicolumn{1}{c}{ Properties } & \multicolumn{1}{c}{ SIKAFLUID®-300. } \\
\hline Aspect & Dark brown \\
Specific gravity & $1.195 \pm 0.015$ \\
$\mathrm{pH}$ & $7.5 \pm 1.5$ \\
Chloride ion content & $<0.1 \%$ \\
Maximum alkali content & $<4 \%$ \\
Solid content & $40 \pm 1 \%$ \\
Recommended dosage & $0.5-3 \%$ by cement weight \\
\hline
\end{tabular}

\section{Aggregates}

Locally available natural sand with $5.12 \mathrm{~mm}$ maximum size was used as fine aggregate, having specific gravity, fineness modulus and unit weight and crushed stone with $20 \mathrm{~mm}$ maximum size having specific gravity, fineness modulus and unit weight was used as coarse aggregate. Both fine aggregate and coarse aggregate conformed to Standard Specifications NA EN 933-1[30]. Table 6 gives the physical properties of the coarse and fine aggregates. 
Table 6. Physical Properties of Coarse and Fine Aggregates

\begin{tabular}{lcc}
\hline \multicolumn{1}{c}{ Physical tests } & Coarse aggregate & Fine aggregate \\
\hline Specific gravity & 2.71 & 2.57 \\
Fineness modulus & 6.74 & 2.62 \\
Bulk density $\left(\mathrm{kg} / \mathrm{m}^{3}\right)$ & 1556 & 1772 \\
Absorption capacity $(\%)$ & 0.43 & 1.17 \\
\hline
\end{tabular}

\section{RESULTS AND DISCUSSION}

\section{$\underline{\text { Tests on cement }}$}

Portland cement mortar was prepared at a water-cement ratio of $\mathrm{W} / \mathrm{C}=0.35$ and sand/cement ratio $(\mathrm{S} / \mathrm{C}=3)$. Maximum amount of black liquor pulp added to the mix was limited to $2.5 \%$ because addition of higher amount of black liquor in concrete pulp leads to decrease in workability.

As the mixing sequence affect the properties of cement and concrete a uniform mixing sequence was adopted for preparing the mixes (Table 7). We set the $\mathrm{W} / \mathrm{C}$ ratio to 0.35 and used five dosages of black liquor $(0.5,1,1.5,2$ and $2.5 \%)$ by cement weight. Portland cement and aggregate were dry mixed first for two minutes and then water was added to the mix and mixed for 1 minute.

Table 7. Mix proportion of cement past

\begin{tabular}{|c|c|c|c|c|c|}
\hline $\begin{array}{c}\text { Mix } \\
\text { designation }\end{array}$ & Cement (g) & Sand (g) & Water (g) & $\mathrm{W} / \mathrm{C}$ & $\begin{array}{l}\text { Black liquor dosages } \\
\text { (g) }\end{array}$ \\
\hline$M 0 \% B L$ & 410 & 1240 & 143.5 & & 0.0 \\
\hline$M 0.5 \% B L$ & 410 & 1240 & 143.5 & & 2.05 \\
\hline$M 1 \% B L$ & 410 & 1240 & 143.5 & 0.35 & 4.10 \\
\hline$M 1.5 B L$ & 410 & 1240 & 143.5 & & 6.15 \\
\hline$M 2 \% B L$ & 410 & 1240 & 143.5 & & 8.20 \\
\hline$M 2,5 \% B L$ & 410 & 1240 & 143.5 & & 10.25 \\
\hline
\end{tabular}

The properties of high performance concrete, mainly in the fresh state are governed by the flow behavior of the paste phase, which is controlled by the dispersion of cement particles by the superplasticizer [31]. In this study, experimental procedures for evaluating the flow behavior of mortar with different dosages of black liquor are studied. The rheological nature of the cement is represented through the Bingham and "Herschel-Bulkley" models [32].

Rheological tests on cement can be used to study the effect of the changes in cement, type and dosage of admixtures, such as superplasticizers, on paste characteristics like yield stress and plastic viscosity [33-37]. The principle is to apply different shear rates to the cement paste in a viscometer and measure the corresponding shear stresses. Generally, a loading-unloading cycle is applied to the cement paste, preceded by some pre-shearing, and the response during unloading is used to determine the rheological parameters [38-39]. Cement paste exhibits shear-thinning behavior, where the slope of the shear stress versus shear strain rate curve decreases with an increase in the shear rate. Such shear-thinning response is attributed to the structural breakdown and rebuilding that takes place in the cement paste [40], with the former mechanism predominating [41]. 
In the present study, a Brookfield HA DV II + Pro viscometer was used with a coaxial cylinder setup (Griffin Beaker of $600 \mathrm{ml}$ in low form).

The shear stress-strain behaviour of mortar paste has been represented using several models [33], [42-44], the Herschel-Bulkley model, show Eq. (1) qualified more versatile model has been used by several researchers [32]:

$$
\tau=\tau_{0}+k \dot{\gamma}^{n}
$$

Where $\tau$ is the shear stress in $(\mathrm{Pa}), \dot{\gamma}$ is the shear strain rate $(1 / \mathrm{s}), \mathrm{n}$ is the power index, $\mathrm{k}$ is the consistency (Pas), and $\tau_{0}$ is the yield stress $(\mathrm{Pa})$.

\section{Rheological behavior of cement pastes}

The curves of shear stress and viscosity according to shear rate for different dosages of black liquor $(0.5,1,1.5,2$ and $2.5 \% \mathrm{wt} \%$ cement), are shown in Figure 5.

The results show that fluidity increases with an increase in dosage of black liquor up to the saturation dosage, who equal to $(2 \%)$ for $\mathrm{M} 2 \% \mathrm{BL}$. We also notice that at a certain dosage the dough flows without any effort (absence of the yield value) is the saturation point $(2 \%)$ for $\mathrm{M} 2 \% \mathrm{BL}$, causing the decrease of the flow threshold (threshold constraint). The higher the percentage of black liquor increases the viscosity of the dough decreases until it is constant (almost Newtonian flow); this is due to the dispersing effect of the black liquor, which adsorbs at the cement grain interface, creating repulsive forces between the particles, reducing or eliminating the adhesion between adjacent particles [45].

Black liquor acts positively and specifically on the rheological properties of cement pastes. The intrinsic rheological parameters of the cement are determined by smoothing the experimental points of the rheograms. The smoothing model is that of Herschel-Bulkley (Equation 1).

Considering the case of the cement without the addition of the black liquor (BL), its rheogram and represented on the Figure 5. (a). Smoothing with the Hershel-Bulkley model leads us to the following rheological parameters; $\tau_{2}=-0.07 \mathrm{~Pa}$ and a viscosity of $\mu=6.209$ Pa.s.

Substitution of water by black liquor gives rheograms to a rheo-thickening behavior and the viscosity of the mortar decreases. The best smoothing is recorded in the formulation (M2\% BL) show Figure 5.(e). The parameters carried by the smoothing of the experimental points with the Hershek-Bulkly model are very good, the viscosity: $\mu=0.01103$ Pa.s and yield stress $\tau_{0}=2.494 \mathrm{~Pa}$. This behavior is similar to that of self-compacting concretes with a fluidity index $\mathrm{n}>1$, which corresponds to rheo-thickening behavior which is generally reported in the literature [46].

Moreover, the addition of $2 \% \mathrm{BL}$ with a $\mathrm{W} / \mathrm{C}=0.35$ begets a better fluidity with the absence of segregation, the emulsifying aspect of the black liquor restrains the grains of cement, which separates the coarse grains by decreasing the friction between them.

The black liquor tested resulted in pastes with good fluidity, when the corresponding saturation dosages were used. It is concluded that the cement-black liquor combinations studied here are all compatible as far as the flow behavior is concerned. 

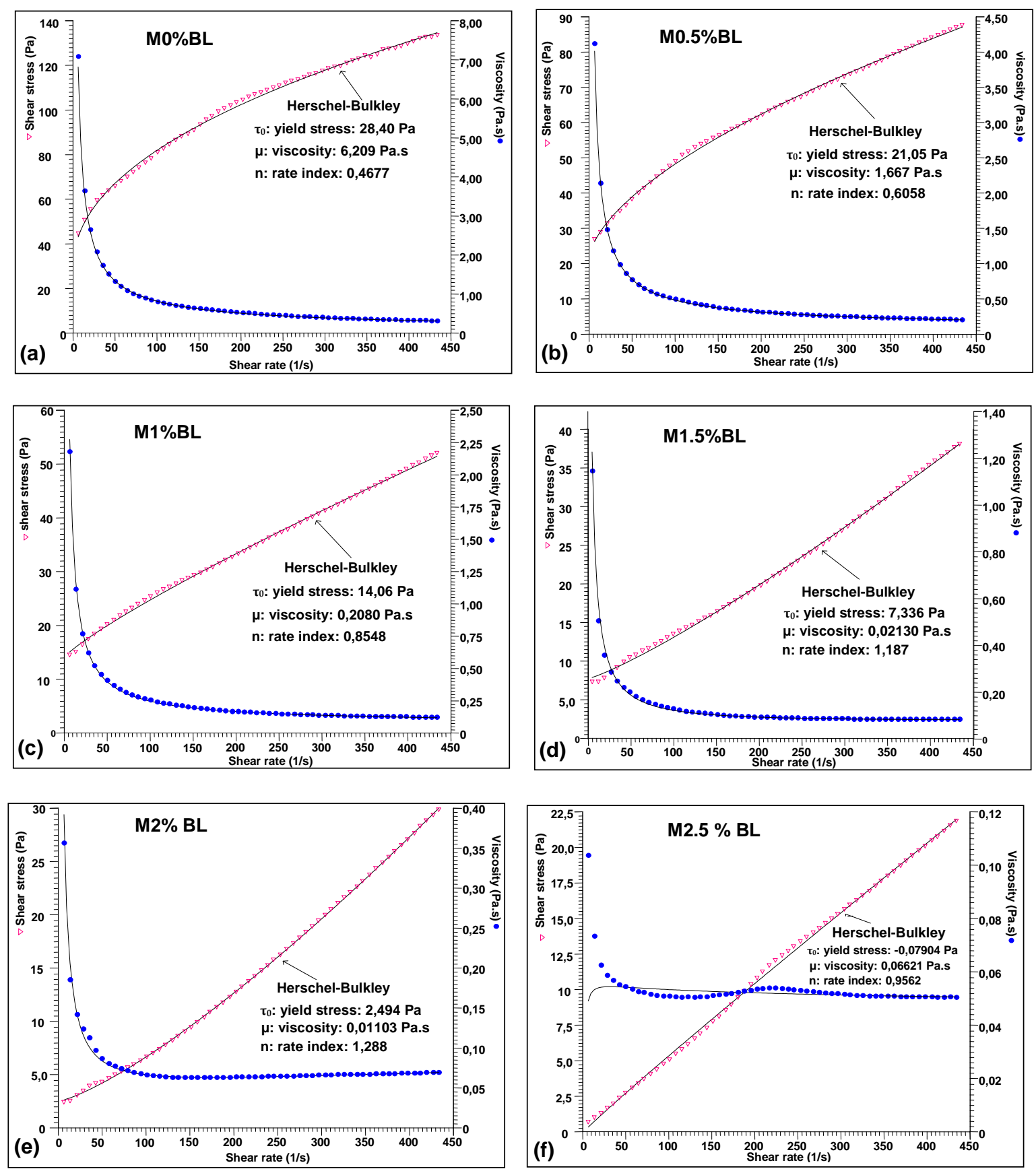

Fig. 5. Curves of Shear stress and viscosity versus shear rate flow for the $0.35 \mathrm{~W} / \mathrm{C}$ cement pastes investigated at various black liquor concentrations. (a)M0\%BL; (b)M0.5\%BL; (c)M1\%BL; (d)M1.5\%BL;

(e)M2\%BL; (f)M2.5\%BL

\section{Tests on concrete}

The effectiveness of black liquor in preparing self concrete is checked by using a replacement of water with $2 \% \mathrm{BL}$. In order to compare the results, concrete is made using commercially available lingo-sulphate superplasticizer also. For this purpose, we used the Dreux Gorisse method for formulation mixing. 
Table 8 summarizes the mix proportions used for production of the concretes. The original concretes were designated in $(\mathrm{CW})$, the concretes with superplasticizer admixture (SIKAFLUID®-300) designated (C2\%SF300), whereas the concretes with $2 \%$ of black liquor designated $(\mathrm{C} 2 \% \mathrm{BL})$. The water/ cement ratios $(\mathrm{W} / \mathrm{C})$ of concretes are similar to those for the concretes $(\mathrm{W} / \mathrm{C}=0.35)$. In order to achieve a similar degree of workability for all three types of concrete.

Table 8. Mix proportion of concrete

\begin{tabular}{|c|c|c|c|c|c|c|c|}
\hline \multirow{2}{*}{$\begin{array}{c}\text { Mix } \\
\text { designation }\end{array}$} & \multicolumn{4}{|c|}{ Mix proportions $\left(\mathrm{kg} / \mathrm{m}^{3}\right)$} & \multirow{2}{*}{$\begin{array}{l}\text { Water } \\
\left(1 / \mathrm{m}^{3}\right)\end{array}$} & \multirow{2}{*}{$\begin{array}{c}\mathrm{BL} \\
\left(1 / \mathrm{m}^{3}\right)\end{array}$} & \multirow{2}{*}{$\begin{array}{c}\text { SIKAFLUID }{ }^{\circledR}-300 \\
\left(1 / \mathrm{m}^{3}\right)\end{array}$} \\
\hline & Cement & Sand & $\begin{array}{c}\text { Aggregate } \\
3 / 8\end{array}$ & $\begin{array}{c}\text { Aggregate } \\
8 / 15\end{array}$ & & & \\
\hline CW & 400 & 660 & 255 & 868 & 140 & -- & -- \\
\hline C $2 \%$ SF 300 & 400 & 660 & 255 & 868 & 140 & -- & 8 \\
\hline $\mathrm{C} 2 \% \mathrm{BL}$ & 400 & 660 & 255 & 868 & 140 & 8 & -- \\
\hline
\end{tabular}

\section{Slump test}

The workability of concrete mixtures with a replacement of $2 \%$ wt Cement by black liquor and superplasticizer (SIKAFLUID ${ }^{\circledR}-300$ ) determined in accordance with the provisions of the Algerian standard NA 431[47]. The Table 9 shows the variation of the slump test (Abrams cone test) as a function of time (minutes) of the three formulations. It was observed that there was an increase in workability by increasing the slump values of the sample $(\mathrm{C} 2 \% \mathrm{BL})$ relative to the control $(\mathrm{CW})$. Slump increasing is compared in Table 9, which shows that concretes $(\mathrm{C} 2 \% \mathrm{SF} 300)$ and $(\mathrm{C} 2 \% \mathrm{BL})$ produced a high slump until 30 minutes, whereas cement (CW) had a slump less weak compared to two other concretes until the hardening at (180 minutes). The fluidity of the concrete grout decreases with time due to the hydration phenomenon of the cement constituents [48-50].

Table 9. Slump test of concrete

\begin{tabular}{cccc}
\hline Time $(\min )$ & \multicolumn{3}{c}{ Slump test $(\mathrm{mm})$} \\
\cline { 2 - 4 } 0 & $\mathrm{CW}$ & $\mathrm{C} 2 \%$ SF300 & $\mathrm{C} 2 \% \mathrm{BL}$ \\
\cline { 2 - 4 } 30 & 73 & 180 & 165 \\
60 & 61 & 138 & 126 \\
90 & 49 & 98 & 87 \\
120 & 35,5 & 65 & 51 \\
150 & 21,2 & 42 & 31 \\
180 & 7,8 & 22 & 13 \\
\end{tabular}

Obviously, the rate of slump loss for mixtures $(\mathrm{C} 2 \% \mathrm{SF} 300)$ and $(\mathrm{C} 2 \% \mathrm{BL})$ is higher than that of a mixture $(\mathrm{CW})$.

Slump of $(\mathrm{C} 2 \% \mathrm{BL})$ is similar to that of the mixture $(\mathrm{C} 2 \% \mathrm{SF} 300)$, and this explains the same role that black liquor plays in the fluidity of the mortar and thus confirms the rheological behavior illustrated in Fig. 5. The black liquor acts as a dispersing agent by neutralizing the electrostatic charges of the concrete mixture, especially the cement. This neutralization minimizes agglomeration of the solid particles allowing them to mix better with water [51]. 


\section{Compressive strengths of concrete}

Compressive strength of concrete is one of the most important and useful properties. As a construction material, concrete is employed to resist compressive stresses. While, at locations where tensile strength or shear strength is of primary importance, the compressive strength is used to estimate the required property.

Table 10. Compressive strengths of concrete

\begin{tabular}{cccccc}
\hline & \multicolumn{5}{c}{ Compressive strengths (MPa) } \\
\cline { 2 - 5 } Mix designation & 2 days & 7 days & 14 days & 28 days & 90 days \\
\hline CW & 6,53 & 17,95 & 24,89 & 43,056 & 47,23 \\
C2\%SF300 & 7,86 & 19,83 & 28,45 & 47,96 & 53,21 \\
C2\%BL & 6,93 & 18,036 & 26,67 & 46,35 & 53,69 \\
\hline
\end{tabular}

Compressive strength tests were conducted on cured cube specimen provisions of the standard (NF EN 12930-3) [52] (150mm.150mm.150mm) at 2,7,14, 28 and 90 days age using a compression testing machine of 300 tons capacity. The load was then slowly applied to the tested cube until failure. Table 10 show the average value of concrete cube compressive strength in different ages for concrete mix and mixes containing ( $2 \%$ of Water content) black liquor (BL) and superplasticizer (SIKAFLUID®-300).

The compressive strength of the hardened concrete pastes was generally increased with curing time up to 90 days, as expected from the continuous hydration process. The apparent porosity decreased gradually and the compactness of samples improved, hence the bulk density increased [53].

The effect of $2 \%$ BL addition was beneficial in concrete. It might be explained by activation of the - $\mathrm{OH}$ - groups present in the black liquor (BL).

The (BL) solution in the hydration water led to the formation of electrostatic repulsive forces between cement particles which become negatively charged by the adsorption. This will reduce the attraction between the cement particles, preventing their flocculation or agglomeration and then creating a well-dispersed system. Consequently, the compactness will enhance and direct benefits are expected on the mechanical resistance.

The results of compressive strength obtained indicate a relatively slow rate of hydration (compressive strength values very close for the three concretes tested) during the early ages of hydration up to 14 days, followed by increasing compressive strength up to 28 days of hydration. These results are attributed to retarding effect of setting time of black liquor leading to the formation and later accumulation of hydration products, namely as calcium silicate hydrates (CSH-I, CSH-II), which act as a good binding centers between the remaining unhydrated cement grains.

On the other hand the rate of increase in the compressive strength values during the period from 7 to 28 days is due to the fact that the initially formed hydration products shielded the remaining unhydrated parts of cement grains leading to a quick rate of hydration during this period [33] [42].

The $(\mathrm{C} 2 \% \mathrm{BL})$ hardened pastes showed nearly the same trend as in case of (C2\%SF300), but with a notable lower values of compressive strength especially during the early ages of hydration (up to 14days). After 28 days of hydration specimens made from (C2\%BL) showed a slight higher value of compressive strength than $(\mathrm{C} 2 \% \mathrm{SF} 300)$ and showed the highest strength value among all tested specimens after 90 days. Either a compressive strength gain of $10 \%$ at 28 days and $12 \%$ at 90 days. 
The compressive strength of concrete after curing showed growth trends as time increased, which indicated that BL was advantageous for the improvement of the long-term compressive strength of concrete though retarding effect was observed in the initial stage of cement hydration.

\section{CONCLUSIONS}

The use of black liquor isolated from date palm wood has a very important scientist and economic interest. Black liquor is considered as a low cost admixture to increase the workability and compressive strength of concrete.

The results of this research show that black liquor produced from date palm trunk noticeably increases the workability of concrete with maximum performance at $2 \%$ water replacement by black liquor.

Effects of dosage of black liquor on the rheological properties of mortar and the rheological curves which have been studied to determine the saturation dosage. The yield stress and the plastic viscosity stress were dramatically decreased at dosage of $0.5-2 \mathrm{wt} \%$, compared with the sample without BL.

Both the Herschel-Bulkley and Bingham models fit the experimental data from the viscometer study satisfactorily. It is observed that the nature of flow in superplasticized paste varies slightly with the dosage of black liquor, as follows. At lower dosages, nonlinear shear thinning is generally observed; around the saturation dosage the response follows the Bingham model; and at higher dosages, there may be some shear thickening.

The yield stress values obtained with both the models have the same trend with respect to black liquor dosage, though the values from the Bingham model tend to be higher at smaller black liquor dosages. Even though shearthickening nature of paste is better represented through the Herschel-Bulkley model, the Bingham model represents the behavior of normal pastes well.

An increase in black liquor dosage leads to a decrease in the yield stress, plastic viscosity, and an increase in minislump spread, as long as the dosages are below the saturation point. Beyond the saturation dosage ( $2 \%$ of Water content), these parameters are practically constant.

The values of compressive strength for hardened pastes made of in $2 \%$ black liquor showed a notable lower values especially during the early ages of hydration (up to 14 days), and showed a comparable and/or higher values after 28 days of hydration as compared to the control concrete $(\mathrm{CW})$.

Black liquor has similar performance compared to the commercially available SIKAFLUID ${ }^{\circ}-300$ admixture for making self-compacting concrete and it is observed that processed black liquor is effective in producing self compacting concrete.

\section{REFERENCES}

1. Demesa A., Laari A., Sillanpää M., Koiranen T. Valorization of lignin by partial wet oxidation using sustainable heteropoly acid catalysts. Molecules, 22 (2017) 1625.

2. Tao C.; Kutchko B.G.; Rosenbaum E.; Wu W.-T.; Massoudi, M. Steady flow of cement slurry. Energies, 12(13) (2019) 2604. 
3. Ahmad M., Taylor C.R., Pink D., Burton K., Eastwood D., Bending G.D., Bugg T.D. Development of novel assays for lignin degradation: comparative analysis of bacterial and fungal lignin degraders. Molecular BioSystems, 5 (2010) 815-821.

4. Ferraris C.F. Measurement of the rheological properties of high performance concrete: state of the art report. Journal of Research of the National Institute of Standards and Technology, 104(5) (1999) 461-478.

5. Cyr M., Legrand C., Mouret M. Study of the shear thickening effect of superplasticizers on the rheological behaviour of cement pastes containing or not mineral additives. Cement and Concrete Research, 30 (2000) 1477-1483.

6. Jayasree C., Gettu R. Experimental study of the flow behaviour of superplasticized cement paste. Materials and Structures, 41(2008) 1581-1593.

7. Panaseti P., Damianou,Y., Georgiou G.C., Housiadas K.D. Pressure-driven flow of a HerschelBulkley fluid with pressure-dependent rheological parameters. Physics of Fluids, 30(3) 2018 030701 .

8. Dalmas Guo-Hua. La biolignine TM : structure et application a l'élaboration de la résine époxy. Doctorat Thesis , Institut National Polytechnique de Toulouse, (2011).

9. De Larrard F., Ferraris C.F., Sedran T. Fresh concrete: a Herschel-Bulkley material. Materials and Structures, 31(1998) 494-498.

10. Djebien R., Belachia M., Hebhoub H. Effect of marble waste fines on rheological and hardened properties of sand concrete. Structural Engineering and Mechanics, 53(6) (2015) 1241-1251.

11. Achinivu E. Protic ionic liquids for lignin extraction-A lignin characterization study. International Journal of Molecular Sciences, 19(2) (2018) 428.

12. Chen F., Shahabadi S.I.S., Zhou D., Liu W., Kong J., Xu J., Lu X. Facile preparation of crosslinked lignin for efficient adsorption of dyes and heavy metal ions. Reactive and Functional Polymers, 143 (2019) 104336.

13. Li X., Li M., Pu Y., Ragauskas A.J., Klett A.S., Thies M., Zheng Y. Inhibitory effects of lignin on enzymatic hydrolysis: The role of lignin chemistry and molecular weight. Renewable Energy, 123 (2018) 664-674.

14. Goisis M., Buscema A., De Marco T. Characterization of the rheological properties of cement paste prepared with polycarboxylate type superplasticizer. Seventh CANMET/ ACI. International Conference on Superplasticizers and Other Chemical Admixtures in Concrete, Berlin (2003).

15. Uchikawa H., Sawaki D., Hanehara S. Influence of kind and added timing of organic admixture on the composition, structure and property of fresh cement paste. Cement and Concrete Research, 25 (2) (1995) $353-364$.

16. Sella Kapu N., Trajano H.L. Review of hemicellulose hydrolysis in softwoods and bamboo. Biofuels Bioprod Biorefin, 8(2014) 857-870.

17. Kim H.Y., Lee E.S., Kim W.S., Suh D.J., Ahn B.S. Material and heat balances of bioethanol production process by concentrated acid saccharification process from lignocellulosic biomass. Clean Technology, 17(2) (2011) 156-165.

18. Kline L.M., Hayes D.G., Womac A.R., Labbe N. Simplified determination of lignin content in hard and soft woods via UV-spectrophotometric analysis of biomass dissolved in ionic liquids. BioResources. 5(3) (2010) 1366-1383.

19. Helnan-Moussa B., Vanhove Y., Wirquin E. Thixotropic behaviour and structural breakdown of fresh cement paste: Comparison between two types of VMA. Advances in Cement Research, 25(4) (2013) 235-244.

20. Li J. Isolation of lignin from wood. Saimaa University of Applied Sciences, Imatra. Unit of 
Technology, Degree Programme in Paper Technology. Bachelor's Thesis (2011) 57.

21. Lim J.H., Lee G.C. Effect of blast furnace slag on rheological properties of fresh mortar. Journal of the Korea Institute of Building Construction, 14(4) (2014) 285-291.

22. A. Irekti, B. Bezzazi, A. Smith, C. Aribi. Experimental Study of Dielectric Properties of Composite Materials Pozzolan/DGEBA" Journal Polymer Composites, 38(2) (2017).

23. Clément Celhay Céline E. Mathieu Laure Candy. Aqueous extraction of polyphenols and antiradicals from wood by-products by 4 twin-screw extractor: Feasibility study. Comptes Rendus Chimie, 17(3) (2014).

24. M.Fasching, P.Schröder, R.Wollboldt, H.Weber, H. Sixta. A new and facile method for isolation of lignin from wood based on complete wood dissolution. Holzforschung, 62(2008) 15-23.

25. M. Saric-Coric, K.H. Khayat, A. Tagnit-Hamou. Performance characteristics of cement grouts made with various combinations of high-range water reducer and cellulose based viscosity modifier. Cement and Concrete Research, 33 (12) (2003)1999-2008.

26. Stryczek S., Wiśniowski R., Gonet A., Złotkowski A., Ziaja J. Influence of polycarboxylate superplasticizers on rheological properties of cement slurries used in drilling technologies. Archives of Mining Sciences, 58 (3) (2013) 719-728.

27. Nehdi M., Rahman M.A. Estimating rheological properties of cement pastes using various rheological models for different test geometry, gap and surface friction. Cement and Concrete Research, 34 (2004) 1993-2007.

28. NA 231, Testing cement methods - Determination of the finesse, Algerian standard, (2006).

29. NA 774, Admixtures for concrete, Definitions, requirements, conformity, marking and labeling, Algerian standard, (2006).

30. NA EN 933-1, Granulometric analysis of aggregates (sand and gravel), Algerian standard (2009).

31. Jayasree C., Gettu R. Experimental study of the flow behaviour of superplasticized cement paste. Materials and Structures, 41(9) (2008) 1581-1593.

32. Qian Y., Kawashima S. Distinguishing dynamic and static yield stress of fresh cement mortars through thixotropy. Cement and Concrete Composites, 86 (2018) 288-296.

33. Irekti A., Bezzazi B. Rheological study of composite materials based on thermosetting matrix and fillers mineral. Key Engineering Materials, 550 (2013) 79-84.

34. Oualit M., Irekti A., Brahim H.A.M.I. Evaluation of the performance of local cement for oil well cementing operations in Algeria. Journal of Materials and Engineering Structures, 5(13) (2018) $5-13$.

35. Oualit M., Irekti A., Melinge Y. Saturation point of superplasticizers determined by rheological tests for self compacting concrete. Periodica Polytechnica Civil Engineering, 62(2) (2017) 346352.

36. Papo A., Piani L. Effect of various superplasticizers on the rheological properties of Portland cement pastes. Cement and Concrete Research, 34 (2004) 2097-2101.

37. Park J., Kim J.Y., Choi J.W. Degradation of plant lignin with the supercritical ethanol and Ru/C catalyst combination for lignin-oil. Journal of the Korean Wood Science and Technology, 43(3) (2015) 355-363.

38. Ralph J., Lundquist K., Brunow G., Lu F., Kim H., et al. Lignins: natural polymers from oxidative coupling of 4-hydroxyphenylpropanoids. Phytochemistry Reviews, 3 (2004) 29-60.

39. Kossakowski P.G., Raczkiewicz W. Comparative analysis of measured and predicted shrinkage strain in concrete. Advances in Materials Science, 14 (2) (2014) 5-13. 
40. Roussel N., Coussot P. "Fifty cent rheometer" for yield stress measurements: From slump to spreading flow. Journal of Rheology, 49(3) (2005) 705-718.

41. El-Mekkawi S.A., Ismail I.M., El-Attar M.M., Fahmy A.A., Mohammed S.S. Utilization of black liquor as concrete admixture and set retarder aid. Journal of Advanced Research, 2 (2011) 163169.

42. Abo-El-Enein S.A., El-Gamal S.M.A., Aiad I.A., Azab M.M., Mohamed O.A. Early hydration characteristics of oil well cement pastes admixed with newly prepared organic admixture. HBRC Journal, 14 (2018) 207-214.

43. Shen L., Chepelev I., Liu J., Wang W. Prediction of quantitative phenotypes based on genetic networks: a case study in yeast sporulation. BMC Systems Biology, 4 (128) (2010).

44. Irekti A., Bezzazi B., Boualam C., Aribi C., Dilmi H. FTIR analysis and rheological behavior of bisphenol: a diglycidyl ether resin filled fume-silica. Journal of Materials Science and Engineering A, 4 (11) (2014) 340-347.

45. Stewart J.J., Akiyama T., Chapple C., Ralph J., Mansfield S.D. The effects on lignin structure of overexpression of ferulate 5-hydroxylase in hybrid poplar. Plant Physiology, 150 (2009) 621-635.

46. Laurichesse S., Avérous L. Chemical modification of lignins: Towards biobased polymers. Progress in Polymer Science, 39 (7) (2014) 1266-1290.

47. NA 431, Determination of the consistency of fresh concrete-slump tests, Algerian standard, (2003).

48. Kalami S., Nejad M. Choosing the right lignin for phenolic adhesive application. International Journal of Chemical and Molecular Engineering, 11(3) (2017).

49. Raczkiewicz W., Bacharz M., K. Bacharz. Experimental verification of the concrete shrinkage strains course according to EN 1992-2 standard. Advances in Materials Science, 15 (2) (2015) $22-29$.

50. Yan T., Xu Y., Yu C. The isolation and characterization of lignin of kenaf fiber. Journal of Applied Polymer Science, 114 (2009) 1896-1901.

51. Li Y. Synthesis and super retarding performance in cement production of diethanolamine modified lignin surfactant. Construction and Building Materials, 52 (2014) 116-121.

52. NF EN 12930-3, Compressive strength of test specimens, French standard, France, (2003).

53. Yuan Q., Xiang Y., Yan Z., Han C., Jan L.Y., Jan Y.N. Light-induced structural and functional plasticity in Drosophila larval visual system. Science, 333(6048) (2011) 1458-1462. 